\title{
Recognition of Trace Element Contamination Using Ficus macrophylla Leaves in Urban Environment
}

\author{
Maria Grazia Alaimo and Daniela Varrica *(D) \\ Dipartimento Scienze della Terra e del Mare (DiSTeM), Via Archirafi 22, 90123 Palermo, Italy; \\ mariagrazia.alaimo@unipa.it \\ * Correspondence: daniela.varrica@unipa.it
}

Received: 26 November 2019; Accepted: 29 January 2020; Published: 31 January 2020

check for updates

\begin{abstract}
Urban areas are characterized by numerous pollutants emitted by anthropic sources both in the form of solid and gaseous particulates. Biomonitoring is an easy, economical, and accessible approach for the determination of atmospheric pollutants. In this study, we used the leaves of Ficus macrophylla Desf. ex Pers., collected in the city of Palermo (Italy), to determine major and trace elements. Geogenic elements exhibited the highest concentrations, making up $99 \%$ of the weight of the analyzed elements $(\mathrm{Ca}, \mathrm{K}, \mathrm{Mg}, \mathrm{P}, \mathrm{S}, \mathrm{Na}, \mathrm{Fe}$, and $\mathrm{Al})$; they range 21,400 (Ca) to $122 \mu \mathrm{g} \mathrm{g}{ }^{-1}$ (Al). The remaining elements showed median concentrations in the range $47.5-0.05 \mu \mathrm{g} \mathrm{g}^{-1}$ in the following order of abundance: $\mathrm{Sr}>\mathrm{Cu}>\mathrm{Mn}>\mathrm{Zn}>\mathrm{Br}>\mathrm{Rb}>\mathrm{Ba}>\mathrm{Pb}>\mathrm{Cr}>\mathrm{Sb}>\mathrm{As}>\mathrm{Mo}=$ Sc. Cluster analysis, with Spearman's coefficient to measure sample similarity, identified five main groups, namely, three clusters related to the geogenic background and marine spray; one cluster linked to elements essential to plants, and a final group attributed to the influence of traffic emissions. Calculated enrichment factors (EF) showed that the enrichments found for $\mathrm{P}$ and $\mathrm{K}$ were linked to plant metabolism; $\mathrm{Na}$ and $\mathrm{Mg}$ confirmed the role of sea spray; $\mathrm{Cu}$ and $\mathrm{Zn}$ underlined the contribution linked to anthropic processes and the role of micronutrients in plants.. As, $\mathrm{Cr}$, and Mo had EF values ranging from 10 and 20, and $\mathrm{Sb}$ had $\mathrm{EF}>90$. From geochemical distribution maps of $\mathrm{As}, \mathrm{Cr}, \mathrm{Mo}$, and $\mathrm{Sb}$ it was observed that metal and metalloid concentrations were higher in urban areas and immediately decreased as one moved away from these areas. Local pollution sources play a great role in trace element concentrations in airborne particulate matter. The present study confirms that Ficus macrophylla leaves are suitable for screening an urban environment to identify concentrations of inorganic chemicals, since they have high tolerance to pollution.
\end{abstract}

Keywords: air quality; trace elements; biogeochemistry; Ficus macrophylla Desf. ex Pers. leaves; environmental geochemistry

\section{Introduction}

Urban areas are characterized by numerous pollutants emitted by anthropic sources in the form of solid and gaseous particulates [1]. Primary emission sources of anthropogenic air pollutants are car traffic, industrial activities, power plants, and domestic fuel [2,3]. Trace elements released into the atmosphere from various anthropogenic sources pose a threat to human health $[4,5]$ with acute and chronic effects, affecting many different systems and organs [6]. The main manifestations concern diseases of the respiratory (allergies, asthma, and lung emphysema [7]) and cardiovascular systems [8,9], sometimes even degenerating into lung cancer $[10,11]$. In recent years, biomonitoring has received growing favor from the scientific community because it is useful in environmental control programs. Bioaccumulators (1) reflect the elemental ambient conditions; (2) offer a practical way of studying the spatial distribution of airborne contaminants; (3) provide a measure of integrated exposure over a certain period time; (4) are an easy, economical alternative to air sampling filters; 
(5) allow a higher density of sampling sites; and (6) allow an accessible approach for the analytical determination of trace elements [12-14].

Several studies have used lower plants, mosses [15-17], lichens [18-21], and parts of higher plants such as leaves as passive samplers in different areas contaminated by natural and anthropic sources [13,22-24].

Plant leaves are widely used due to their ability to absorb pollutants through stomata and cuticles or indirectly through the roots after the deposition of atmospheric pollutants in the soil [25]. The ability to absorb trace elements through dry or wet deposition depends on leaf surface morphology, which regulates its absorption [26-29]. Some researchers, for example, have used Nerium Oleander L. leaves in environmental geochemical studies to document the presence of trace elements of anthropogenic origin in airborne particulate matter of urban areas [3,23,30,31]. Pine needles have been used to reveal the presence of metal concentrations in the environment, in urban areas [22,32-34], in industrial areas $[24,35]$ and in mining areas [36]. Only a few studies have concerned the use of the genus Ficus for environmental monitoring; in fact, the determination of the content of metals and metalloids has been made on leaves of Ficus Benjamin [37] and Ficus microcarpa [38] in urban environments.

In this study the leaves of Ficus macrophylla Desf. ex Pers. have been chosen to evaluate air quality in the city of Palermo, as there are no monitoring studies in the literature that use this species of Ficus as a biomonitor. This tree species is an evergreen plant which is very common in gardens and along urban avenues, and the morphological structure of leaves could facilitate a dust-retaining capability. The main objective was to determine trace element concentrations, build spatial distribution maps of the metals and metalloids, and identify their local sources.

\section{Materials and Methods}

\subsection{Study-Area Description}

Palermo is the largest urban area of Sicily, having about 680,000 inhabitants and a metropolitan area populated by more than 1 million people. The city is situated on the north-western coast of the island, bordered on the northeast by the Tyrrhenian Sea and surrounded by mountains (Monti di Palermo) reaching 500-1000 m above sea level (Figure 1); the study area is entirely covered by sedimentary rocks (limestone, clay, marly-clay, and white or yellow quaternary biocalcarenite; most of the eastern sector of the Piana di Palermo is covered by a bright red-colored soil rich in Fe-oxides, known as "Terra Rossa") [39,40]. The climate of Palermo is typically Mediterranean, with hot summers and temperate winters. Winds during the autumn months, generally breezes, predominantly originate from the WNW and WSW sectors.

\subsection{General Species Characteristics}

Ficus macrophylla Desf. ex Pers is a species belonging to the genus Ficus Linn. (Moraceae, Magnoliophita). The tree has a large crown composed of branches and shiny and evergreen leaves. It contains a set of roots of various caliber and shape which extend vertically up to the ground with the function of supporting the crown and supplying water to the leaves [41,42]. Usually, adult plants have an average height of $25 \mathrm{~m}$ and a tree-trunk circumference of about $18 \mathrm{~m}$. It is widespread in the city gardens and along major roads of Palermo. The plants arrived in Palermo from Australia at the end of the 17th century and grew in surprising proportions and shapes. The widespread presence of exceptional examples of Ficus macrophylla in Palermo has great aesthetic value for the city [43].

\subsection{Sampling and Analytical Method}

A total of 39 composite samples of several years of leaf growth from Ficus macrophylla Desf. ex Pers were collected in October 2018 (Figure 1). The sampling sites were chosen according to the distribution of all the monumental specimens recorded in the city of Palermo [44]. 


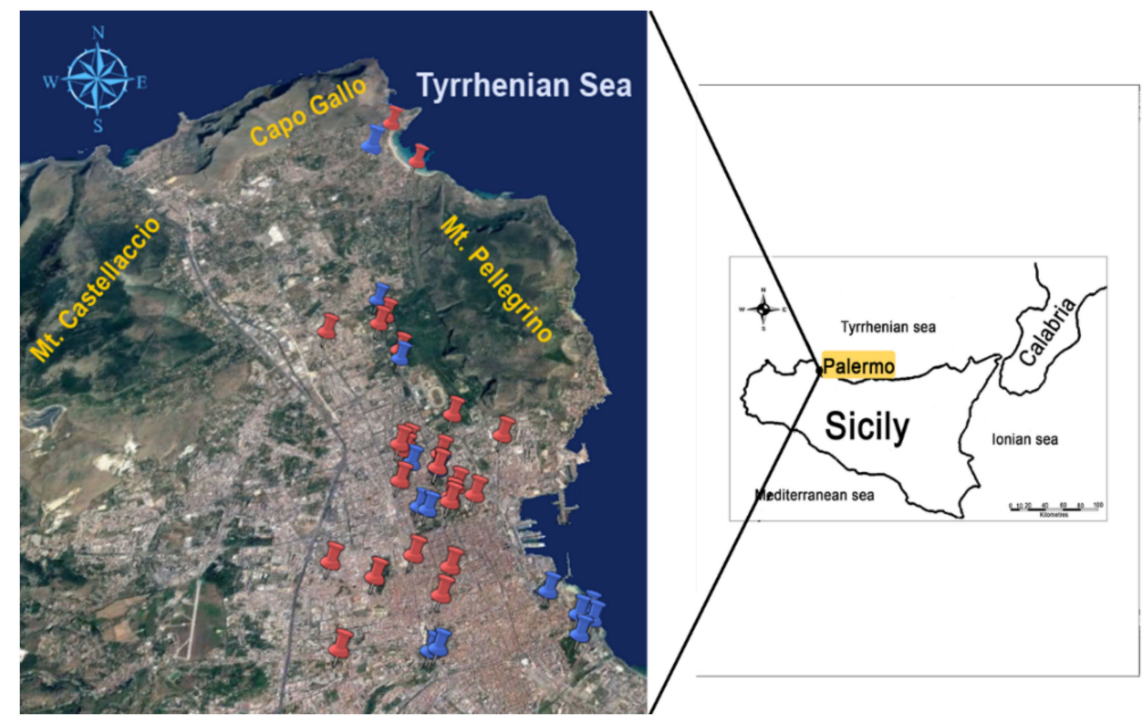

Figure 1. Study area in relation to sampling site location of Ficus macrophylla. Red indicates samples collected from the long main urban road; blue indicates samples collected from city gardens.

In Table 1 we report the location and description of sampling sites. Each sample, made up of several subsamples collected from all over the tree, was stored in a paper bag. The unwashed samples were dried for $48 \mathrm{~h}$ at $40{ }^{\circ} \mathrm{C}$ and then ground to a fine powder. A portion of each sample was analyzed for major and trace elements using instrumental neutron activation analysis (INAA) and inductively coupled plasma optical emission spectroscopy (ICP-OES) ( $\mathrm{Br}, \mathrm{Ca}, \mathrm{K}, \mathrm{Mg}, \mathrm{P}, \mathrm{Na}$, and Sc) at Activation Laboratories Ltd. (Ontario, Canada) using NBS 1572 and 1632B as the standard reference material. The 13 trace elements ( $\mathrm{Al}, \mathrm{As}, \mathrm{Ba}, \mathrm{Cr}, \mathrm{Cu}, \mathrm{Fe}, \mathrm{Mn}, \mathrm{Mo}, \mathrm{Pb}, \mathrm{Rb}, \mathrm{Sb}, \mathrm{Sr}$, and $\mathrm{Zn}$ ) were determined at Dept. Scienze della Terra e del Mare, University of Palermo, using an inductively coupled plasma mass spectrometer (Elan 6100 DRC-e, PerkinElmer) after the addition of Re-Sc-Y as internal standards. For As, $\mathrm{Cr}$, and Fe, the ICP-MS was operated in dynamic reaction cell (DRC) mode with $\mathrm{CH}_{4}$ as the reaction gas. All standard solutions were prepared with $18 \mathrm{M} \Omega \mathrm{cm}$ demineralized water, ICP Multielement Standard Solutions XXI CertiPUR (Merck), and Mo and Sb CertiPUR standards (Merck). Calibration curves ranging 0.05 to $500 \mu \mathrm{g} \mathrm{L}^{-1}$ were constructed. To minimize matrix effects, the standard addition technique was used for all metal determinations. Sample blanks were also analyzed, and the operational limit of detection (LOD) for each element was calculated as three times the standard deviation of the analyte concentration in the blank samples. In order to validate the analytical procedure, standard reference material NIST SRM 1515 Apple Leaves was analyzed for the corresponding elements. Metal recovery rates resulted in good agreement with the certified concentrations, ranging between $89 \%$ and $107 \%$.

Maps were generated using the Surfer Software edited by Golden Software Inc. (Golden, Colorado, USA). The selected gridding method was Kriging [45].

Data were statistically analyzed with the STATISTICA program [46]. All tests in this study were considered significant at $p<0.01$. The Kolmogorov-Smirnov test, with a level of significance set at $p<0.01$, was used to verify the normality of the data distribution. The non-parametric Mann-Whitney test at $p<0.05$ was also used to verify the statistical significance of observed differences between sampling sites. 
Table 1. Sampling sites and location descriptions. Legend: Urb, samples collected from the long main urban road; $C G$, samples collected from city gardens.

\begin{tabular}{|c|c|c|}
\hline Samples & Location & Characteristics \\
\hline FC1 & Urb & urban road exposed to heavy traffic, composed of cars and urban buses \\
\hline FC2 & Urb & urban road characterized by lower traffic density \\
\hline FC3 & Urb & large square exposed to traffic mainly composed of cars and urban buses \\
\hline FC4 & Urb & urban road characterized by lower traffic density \\
\hline FC5 & Urb & urban road characterized by lower traffic density \\
\hline FC6 & Urb & urban road characterized by lower traffic density \\
\hline FC7 & Urb & urban road characterized by lower traffic density \\
\hline FC8 & Urb & urban road exposed to medium amount of traffic of cars \\
\hline FC9 & Urb & urban road exposed to medium amount of traffic of cars \\
\hline FC10 & Urb & urban road exposed to medium amount of traffic of cars \\
\hline FC11 & Urb & urban road exposed to medium amount of traffic of cars \\
\hline FC12 & Urb & $\begin{array}{c}\text { urban road exposed to heavy traffic, composed of cars, heavy-duty vehicles and } \\
\text { urban and extra-urban buses }\end{array}$ \\
\hline FC13 & Urb & urban road exposed to heavy traffic, composed of cars and urban buses \\
\hline FC14 & Urb & $\begin{array}{c}\text { urban road exposed to high traffic flow, composed of cars, heavy-duty vehicles and } \\
\text { urban and extra-urban buses }\end{array}$ \\
\hline FC15 & Urb & $\begin{array}{c}\text { urban road exposed to heavy traffic, composed of cars and urban and } \\
\text { extra-urban buses }\end{array}$ \\
\hline FC16 & Urb & urban road exposed to medium amount of traffic of cars \\
\hline FC17 & Urb & urban road exposed to medium amount of traffic of cars \\
\hline FC18 & Urb & $\begin{array}{l}\text { urban road exposed to high traffic flow, composed of cars, heavy-duty vehicles and } \\
\text { urban buses }\end{array}$ \\
\hline FC19 & Urb & urban road exposed to medium amount of traffic of cars \\
\hline FC20 & Urb & $\begin{array}{c}\text { urban road exposed to high traffic flow, composed of cars, heavy-duty vehicles and } \\
\text { urban and extra-urban buses }\end{array}$ \\
\hline FC21 & Urb & $\begin{array}{l}\text { a little square in front of the railway station, exposed to heavy traffic, composed of } \\
\text { cars and urban and extra-urban buses }\end{array}$ \\
\hline FC22 & Urb & urban road exposed to heavy traffic, composed of cars and urban buses \\
\hline FC23 & Urb & $\begin{array}{c}\text { large square in front of the sea exposed to heavy traffic by cars, urban and } \\
\text { extra-urban buses }\end{array}$ \\
\hline $\mathrm{FC} 24$ & Urb & urban road exposed to heavy traffic composed of cars, urban and extra-urban buses \\
\hline FC25 & Urb & $\begin{array}{c}\text { urban road exposed to high traffic flow, composed of cars, heavy-duty vehicles and } \\
\text { urban and extra-urban buses }\end{array}$ \\
\hline FC26 & CG & urban garden without any direct influence of vehicular traffic \\
\hline FC27 & CG & urban garden without any direct influence of vehicular traffic \\
\hline FC28 & CG & urban garden without any direct influence of vehicular traffic \\
\hline FC29 & CG & urban garden without any direct influence of vehicular traffic \\
\hline FC30 & CG & urban garden without any direct influence of vehicular traffic \\
\hline FC31 & CG & urban garden without any direct influence of vehicular traffic \\
\hline FC32 & CG & urban garden without any direct influence of vehicular traffic \\
\hline FC33 & CG & urban garden without any direct influence of vehicular traffic \\
\hline FC34 & CG & urban garden without any direct influence of vehicular traffic \\
\hline FC35 & CG & urban garden without any direct influence of vehicular traffic \\
\hline FC36 & CG & urban garden without any direct influence of vehicular traffic \\
\hline FC37 & CG & urban garden without any direct influence of vehicular traffic \\
\hline FC38 & CG & urban garden without any direct influence of vehicular traffic \\
\hline FC39 & CG & urban garden without any direct influence of vehicular traffic \\
\hline
\end{tabular}

\section{Results and Discussion}

Table 2 shows the chemical compositions of major and trace elements determined in Ficus macrophylla leaf samples on a dry-weight basis; we also report the mean and standard deviation of samples broken into two groups. "Urb" is representative of samples collected from the long main urban road and "CG" of samples taken in the main city gardens. 
Table 2. Basic statistical parameters for a total of 39 Ficus macrophylla leaf samples. Data given in $\mu \mathrm{g} \mathrm{g}^{-1}$ (dry biomass). Legend: N, number of analyzed samples; Std, standard deviation; MAD, median absolute deviation.

\begin{tabular}{|c|c|c|c|c|c|c|c|c|c|c|c|c|}
\hline & $\mathbf{N}$ & Mean \pm Std & Median & Minimum & Maximum & Skewness & Kurtosis & MAD & $\mathbf{N}$ & URB & $\mathbf{N}$ & CG \\
\hline $\mathrm{Ca}$ & 39 & $21,506 \pm 4195$ & 21,400 & 9850 & 30,350 & -0.27 & 0.85 & 2700 & 25 & $21,748 \pm 3733$ & 14 & $21,075 \pm 5039$ \\
\hline K & 39 & $17,897 \pm 4134$ & 17,800 & 10,100 & 26,700 & 0.19 & -0.64 & 3150 & 25 & $17,220 \pm 3582$ & 14 & $19,107 \pm 4879$ \\
\hline $\mathrm{Mg}$ & 39 & $8239 \pm 1496$ & 7900 & 5700 & 12,000 & 0.64 & 0.10 & 800 & 25 & $8238 \pm 1470$ & 14 & $8242 \pm 1597$ \\
\hline $\mathrm{P}$ & 39 & $1602 \pm 341$ & 1580 & 162 & 2470 & -1.25 & 8.82 & 130 & 25 & $1612 \pm 247$ & 14 & $1585 \pm 477$ \\
\hline $\mathrm{S}$ & 39 & $1253 \pm 177$ & 1240 & 860 & 1730 & 0.43 & 0.44 & 120 & 25 & $1288 \pm 178$ & 14 & $1190 \pm 162$ \\
\hline $\mathrm{Na}$ & 39 & $808 \pm 1509$ & 459 & 265 & 9423 & 5.31 & 29.79 & 116 & 25 & $862 \pm 1794$ & 14 & $714 \pm 836$ \\
\hline $\mathrm{Fe}$ & 39 & $230 \pm 199$ & 175 & 10 & 880 & 2.17 & 4.26 & 55.0 & 25 & $254 \pm 203$ & 14 & $189 \pm 192$ \\
\hline $\mathrm{Al}$ & 39 & $261 \pm 401$ & 122 & 65 & 2500 & 4.88 & 26.7 & 23.0 & 25 & $320 \pm 490$ & 14 & $157 \pm 103$ \\
\hline $\mathrm{Ba}$ & 37 & $9.00 \pm 3.21$ & 9.00 & 5.00 & 15.0 & 0.22 & -0.99 & 3.00 & 25 & $8.41 \pm 2.99$ & 14 & $10.1 \pm 3.43$ \\
\hline $\mathrm{Br}$ & 37 & $20.4 \pm 12.9$ & 17.0 & 6.30 & 80.0 & 2.98 & 12.1 & 6.00 & 25 & $22.8 \pm 14.2$ & 14 & $15.7 \pm 8.94$ \\
\hline $\mathrm{Cr}$ & 37 & $1.06 \pm 0.40$ & 0.90 & 0.60 & 2.40 & 1.40 & 2.16 & 0.20 & 25 & $1.19 \pm 0.42$ & 14 & $0.82 \pm 0.24$ \\
\hline $\mathrm{Cu}$ & 39 & $26.9 \pm 15.0$ & 23.0 & 16.0 & 99.0 & 3.80 & 15.6 & 3.00 & 25 & $26.5 \pm 11.0$ & 14 & $27.8 \pm 20.8$ \\
\hline Mo & 37 & $0.14 \pm 0.12$ & 0.09 & 0.02 & 0.63 & 1.93 & 5.21 & 0.04 & 25 & $0.18 \pm 0.13$ & 14 & $0.07 \pm 0.05$ \\
\hline $\mathrm{Mn}$ & 39 & $22.9 \pm 6.77$ & 22.0 & 14.0 & 45.0 & 1.09 & 1.52 & 5.00 & 25 & $23.4 \pm 6.11$ & 14 & $22.1 \pm 7.98$ \\
\hline $\mathrm{Pb}$ & 39 & $2.61 \pm 1.32$ & 2.65 & 0.49 & 8.00 & 1.76 & 6.13 & 0.75 & 25 & $3.01 \pm 1.39$ & 14 & $1.89 \pm 0.84$ \\
\hline $\mathrm{Rb}$ & 37 & $9.86 \pm 3.78$ & 10.0 & 4.00 & 17.0 & 0.26 & -0.92 & 3.00 & 25 & $9.87 \pm 3.73$ & 14 & $9.84 \pm 4.03$ \\
\hline $\mathrm{Sb}$ & 37 & $0.51 \pm 0.36$ & 0.40 & 0.11 & 1.90 & 1.91 & 4.80 & 0.17 & 25 & $0.61 \pm 0.40$ & 14 & $0.34 \pm 0.19$ \\
\hline $\mathrm{Sr}$ & 39 & $46.1 \pm 12.6$ & 47.5 & 15.5 & 75.5 & -0.05 & 0.20 & 6.50 & 25 & $48.7 \pm 12.7$ & 14 & $41.3 \pm 11.5$ \\
\hline $\mathrm{Zn}$ & 39 & $21.0 \pm 4.09$ & 21.0 & 14.5 & 31.0 & 0.43 & -0.13 & 3.00 & 25 & $21.5 \pm 4.01$ & 14 & $20.1 \pm 4.21$ \\
\hline
\end{tabular}


Most of the analyzed elements, on the basis of the kurtosis and skewness coefficient, showed a leptokurtic distribution with a skew to the right. $\mathrm{Ca}, \mathrm{Mg}$, S, As, $\mathrm{Cr}, \mathrm{Mn}$, and $\mathrm{Sr}$ showed a platykurtic distribution with a skewed to the right, and only $\mathrm{K}, \mathrm{Ba}, \mathrm{Rb}$, and $\mathrm{Zn}$ showed a platykurtic distribution with a skew to the left. The application of the Kolmogorov-Smirnov test confirmed that the data had asymmetric distribution. Typical geogenic elements exhibited the highest concentrations and have been reported in the order of decreasing concentration; other elements are listed in alphabetical order. Major elements generally made up $99 \%$ of the weight of the analyzed elements ( $\mathrm{Ca}, \mathrm{K}, \mathrm{Mg}, \mathrm{P}, \mathrm{S}, \mathrm{Na}, \mathrm{Al}$, and $\mathrm{Fe}$ ) and ranged 21,400 (Ca) to $122 \mu^{-1} \mathrm{~g}^{-1}(\mathrm{Al})$. The great predominance of these elements is not surprising: firstly, $\mathrm{Ca}, \mathrm{Mg}, \mathrm{Fe}, \mathrm{Al}$, and $\mathrm{Na}$, in general, are typical elements linked to the resuspension of soil material and sea spray, and these processes are considered fundamental for the formation of airborne particulate matter, as reported by several studies conducted in Palermo city [22,30,47,48]; secondly, K, P, and S are macronutrients and play an important role in plant growth. The remaining elements showed median concentrations in the range 47.5-0.05 $\mathrm{g} \mathrm{g}^{-1}$ and had the following order of abundance: $\mathrm{Sr}>\mathrm{Cu}>\mathrm{Mn}>\mathrm{Zn}>\mathrm{Br}>\mathrm{Rb}>\mathrm{Ba}>\mathrm{Pb}>\mathrm{Cr}>\mathrm{Sb}>\mathrm{As}>\mathrm{Mo}=$ Sc. In Table 3 we report Spearman's rank correlation matrix $(p<0.01 ; \rho=0.37)$.

Some elements showed a statistically significant positive correlation, indicating a common origin. Correlations between elements were found to suggest a multitude of sources that may contribute to a load of trace elements in Ficus macrophylla leaves.

A useful method employed to simplify the complex data set, with the aim of identifying relationships between variables and possible sources of air pollution, is cluster analysis (CA). The clustering procedure was performed with Spearman's coefficient as a measure of sample similarity. Results are displayed in the bidimensional hierarchical diagram of Figure 2. Five main groups of related elements may be identified at $\rho<0.37(p<0.01)$. Lead is not linked to any of the identified groups. Two clusters are related to the geogenic background: Ba and Ca are representative of Palermo's calcareous substrate, and the second cluster, comprising $\mathrm{Mn}$ and $\mathrm{Al}$, is associated with the clay soil component $[22,39]$. Bromine and strontium are associated with sea spray $[19,22,49,50]$. The group comprising $\mathrm{Cu}, \mathrm{Zn}, \mathrm{Rb}, \mathrm{K}$, and $\mathrm{P}$ represents the essential elements for plants [51].

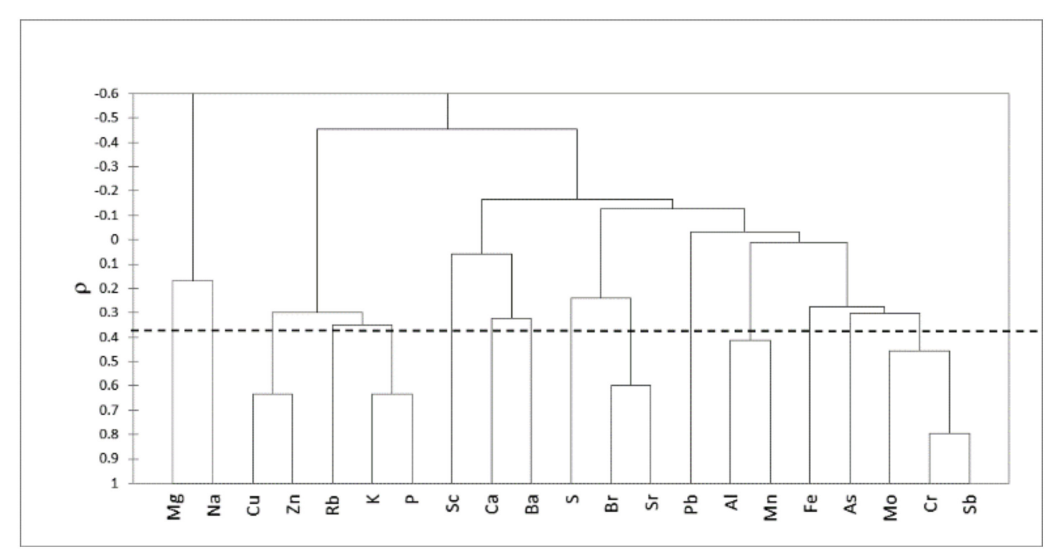

Figure 2. Cluster analysis dendrogram for 39 samples and 21 elements. Cluster analysis was based on Spearman's rank correlation $\rho$.

The last cluster, comprising $\mathrm{Cr}, \mathrm{Mo}$, and $\mathrm{Sb}$, can be attributed to the influence of traffic on air pollution. The elements identified by $\mathrm{CA}$ as geogenic were observed in other biomonitoring studies in Palermo. Several works have reported the fundamental role of calcarenite bedrocks and the local "terra rossa" soil in indicating the crustal origin [22,40,47] of the elements deposited on leaves. Likewise, sea spray has an important contribution to particulate matter concentrations in Palermo. Dongarrà et al. [48] have found that $\mathrm{NaCl}$ concentrations in Palermo constitute $7.4 \%$ of $\mathrm{PM}_{2.5}$ and $11.2 \%$ of $\mathrm{PM}_{10}$ mass levels. 
Table 3. Correlation matrix for selected elements $(p<0.01 ; \rho=0.37)$.

\begin{tabular}{|c|c|c|c|c|c|c|c|c|c|c|c|c|c|c|c|c|c|c|c|c|c|}
\hline \multicolumn{22}{|c|}{ Spearman Matrix Correlation } \\
\hline & Al & $\mathrm{Ca}$ & $\mathrm{Fe}$ & $\mathbf{K}$ & Mg & $\mathrm{Na}$ & $\mathbf{P}$ & $\mathbf{S}$ & As & Ba & $\mathrm{Br}$ & $\mathrm{Cr}$ & $\mathrm{Cu}$ & Mo & Mn & $\mathrm{Pb}$ & $\mathbf{R b}$ & $\mathrm{Sb}$ & Sc & Sr & Zn \\
\hline Al & 1.00 & 0.13 & 0.25 & -0.17 & -0.05 & 0.17 & -0.12 & 0.10 & 0.05 & -0.13 & -0.08 & 0.14 & -0.02 & 0.11 & 0.41 & -0.03 & -0.12 & 0.06 & 0.04 & -0.12 & -0.15 \\
\hline $\mathrm{Ca}$ & & 1.00 & 0.06 & -0.45 & -0.07 & 0.10 & -0.29 & -0.07 & -0.12 & 0.32 & 0.05 & 0.00 & -0.43 & 0.05 & 0.29 & 0.18 & -0.35 & 0.13 & 0.09 & 0.29 & -0.40 \\
\hline $\mathrm{Fe}$ & & & 1.00 & -0.06 & -0.16 & -0.03 & 0.15 & 0.11 & 0.29 & 0.02 & -0.01 & 0.54 & 0.10 & 0.28 & 0.31 & 0.16 & -0.01 & 0.35 & 0.06 & -0.12 & 0.11 \\
\hline $\mathbf{K}$ & & & & 1.00 & -0.22 & -0.25 & 0.63 & -0.19 & 0.23 & 0.06 & -0.21 & 0.08 & 0.36 & 0.07 & -0.20 & -0.15 & 0.51 & 0.03 & 0.06 & -0.38 & 0.33 \\
\hline $\mathrm{Mg}$ & & & & & 1.00 & 0.17 & -0.24 & -0.09 & -0.19 & -0.18 & -0.21 & -0.35 & 0.09 & -0.18 & 0.01 & -0.03 & 0.17 & -0.25 & 0.01 & -0.14 & 0.12 \\
\hline $\mathrm{Na}$ & & & & & & 1.00 & -0.47 & -0.05 & -0.69 & -0.13 & 0.28 & -0.07 & -0.10 & -0.15 & 0.10 & -0.06 & -0.04 & -0.05 & -0.09 & 0.01 & -0.25 \\
\hline $\mathbf{P}$ & & & & & & & 1.00 & 0.16 & 0.59 & 0.24 & -0.01 & 0.29 & 0.31 & 0.07 & -0.06 & -0.23 & 0.35 & 0.15 & 0.15 & -0.23 & 0.41 \\
\hline$S$ & & & & & & & & 1.00 & 0.08 & -0.04 & 0.37 & 0.21 & 0.10 & 0.22 & 0.36 & 0.01 & -0.41 & 0.16 & -0.17 & 0.24 & 0.24 \\
\hline As & & & & & & & & & 1.00 & 0.02 & -0.07 & 0.37 & 0.08 & 0.30 & 0.01 & 0.18 & 0.17 & 0.32 & 0.19 & -0.13 & 0.36 \\
\hline $\mathrm{Ba}$ & & & & & & & & & & 1.00 & 0.10 & 0.01 & 0.04 & -0.06 & 0.02 & -0.15 & -0.22 & 0.12 & 0.06 & 0.07 & 0.05 \\
\hline $\mathrm{Br}$ & & & & & & & & & & & 1.00 & 0.38 & 0.06 & 0.22 & 0.24 & -0.06 & -0.06 & 0.52 & -0.06 & 0.60 & 0.20 \\
\hline $\mathrm{Cr}$ & & & & & & & & & & & & 1.00 & 0.21 & 0.46 & 0.16 & 0.17 & 0.06 & 0.79 & 0.00 & 0.16 & 0.27 \\
\hline $\mathrm{Cu}$ & & & & & & & & & & & & & 1.00 & 0.20 & -0.11 & 0.01 & 0.35 & 0.20 & -0.05 & 0.02 & 0.64 \\
\hline Mo & & & & & & & & & & & & & & 1.00 & 0.16 & 0.15 & -0.05 & 0.50 & 0.23 & 0.03 & 0.25 \\
\hline Mn & & & & & & & & & & & & & & & 1.00 & 0.03 & -0.32 & 0.09 & 0.17 & 0.15 & 0.15 \\
\hline $\mathrm{Pb}$ & & & & & & & & & & & & & & & & 1.00 & -0.09 & -0.01 & -0.13 & 0.16 & 0.17 \\
\hline $\mathbf{R b}$ & & & & & & & & & & & & & & & & & 1.00 & 0.04 & 0.08 & -0.26 & 0.30 \\
\hline $\mathrm{Sb}$ & & & & & & & & & & & & & & & & & & 1.00 & 0.02 & 0.32 & 0.27 \\
\hline $\mathrm{Sc}$ & & & & & & & & & & & & & & & & & & & 1.00 & -0.15 & -0.07 \\
\hline $\mathrm{Sr}$ & & & & & & & & & & & & & & & & & & & & 1.00 & 0.01 \\
\hline $\mathrm{Zn}$ & & & & & & & & & & & & & & & & & & & & & 1.00 \\
\hline
\end{tabular}


To confirm the anthropogenic source of the groups defined from cluster analysis, we calculated the enrichment factors (EF). EFs were calculated by dividing their relative abundance in Ficus macrophylla leaves by their relative average abundance in the local soil: $\mathrm{EF}=(\mathrm{X} / \mathrm{Al})_{\mathrm{FL}} /(\mathrm{X} / \mathrm{Al})_{\mathrm{LS}}$. According to Varrica et al. [34], the average local soil (LS) is considered to be made up of carbonate rocks $(80 \%)$, clay minerals $(10 \%)$, and "terra rossa" soil $(10 \%)$. Aluminum was selected as the reference element (Figure 3).

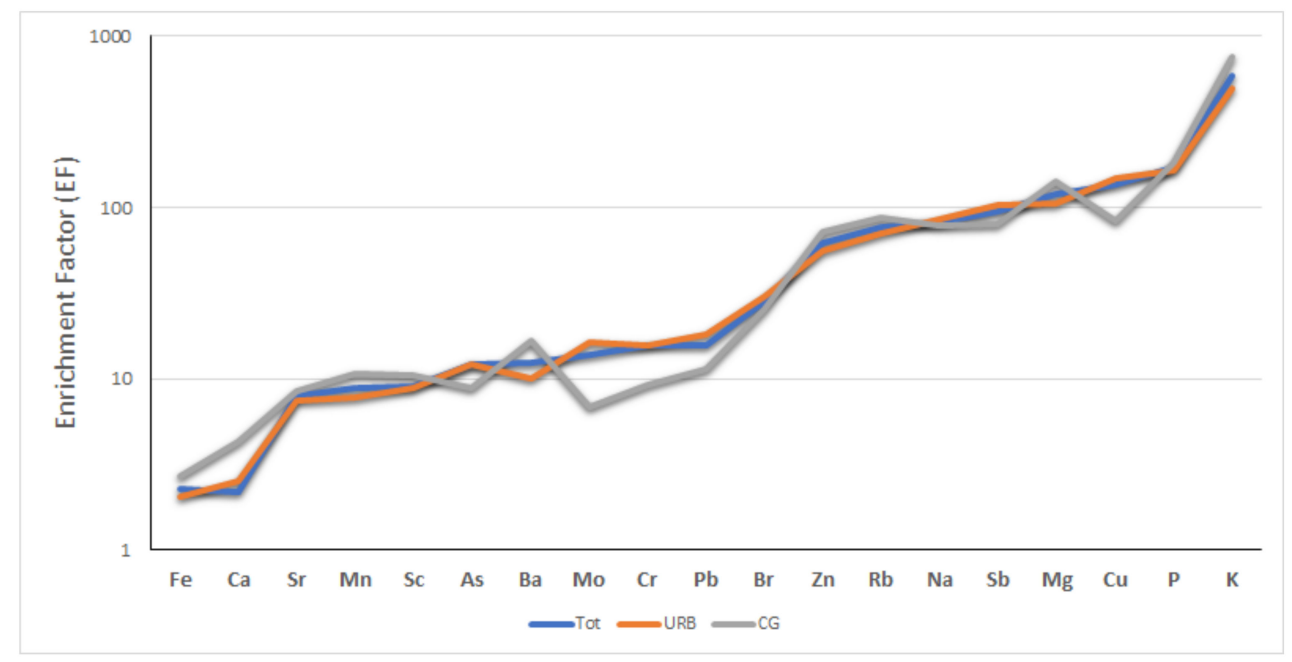

Figure 3. Average enrichment factors (EFs) for the analyzed elements in Ficus macrophylla leaves.

The enrichments found for $\mathrm{P}$ and $\mathrm{K}$ are linked to plant metabolism, and $\mathrm{Na}$ and $\mathrm{Mg}$ confirm the role of sea spray. The EF of $\mathrm{Cu}$ and $\mathrm{Zn}$ underline their contribution linked to both anthropic processes and the role of micronutrients in plants.. Arsenic, $\mathrm{Cr}, \mathrm{Mo}$, and $\mathrm{Sb}$ were found to have EF values ranging from 10 to 100 with respect to the local soil, indicating a source link to vehicular traffic. Other trace elements $(\mathrm{Mn}, \mathrm{Sr}, \mathrm{Ca}$, and Fe) showed $\mathrm{EF}<10$. The same enriched elements were found in particulate matter $\mathrm{PM}_{2.5}$ [48]. We interpret these findings as clear evidence that these metals and metalloids originated from a common source identified in general with gaseous emissions and the mechanical part deterioration of motor vehicles. Arsenic is derived from oil combustion; antimony, chromium, and molybdenum appear to be associated with non-exhaust vehicle emissions, including release by the mechanical abrasion of metal structures of vehicles, engine components, tires, and brake linings $[48,51-56]$. In addition, $\mathrm{Sb}$ concentration in particulate matter has appeared to act as a fingerprinting tool in identifying the contribution of road vehicles to traffic-derived particulate matter $[48,56,57]$. In the past, brake pads were made with asbestos. During the end of the 20th century, with the elimination of asbestos from the market, pads began to be produced by other materials, including fillers such as $\mathrm{Sb}$ sulphates, kaolinite clays, $\mathrm{Mg}$ and $\mathrm{Cr}$ oxides, and metal powders. A study by Rossini Oliva and Rautio [38] on Ficus microcarpa L. leaves growing in Palermo has highlighted the role of vehicular traffic pollution in the contents of some trace elements $(\mathrm{Cr}, \mathrm{Pb}, \mathrm{Ba}$, and $\mathrm{Cu})$ and the decreased content of lead observed over several years in relation to the increase in unleaded petrol use.

The distribution maps of As, $\mathrm{Cr}$, Mo, and $\mathrm{Sb}$, shown in Figure 4, highlight the anthropogenic geochemical anomalies within the study area. Metal and metalloid concentrations are higher in urban areas and immediately decrease as one moves away from these areas, indicating that local pollution sources play a great role in metal and metalloid concentrations in airborne particulate matter. 

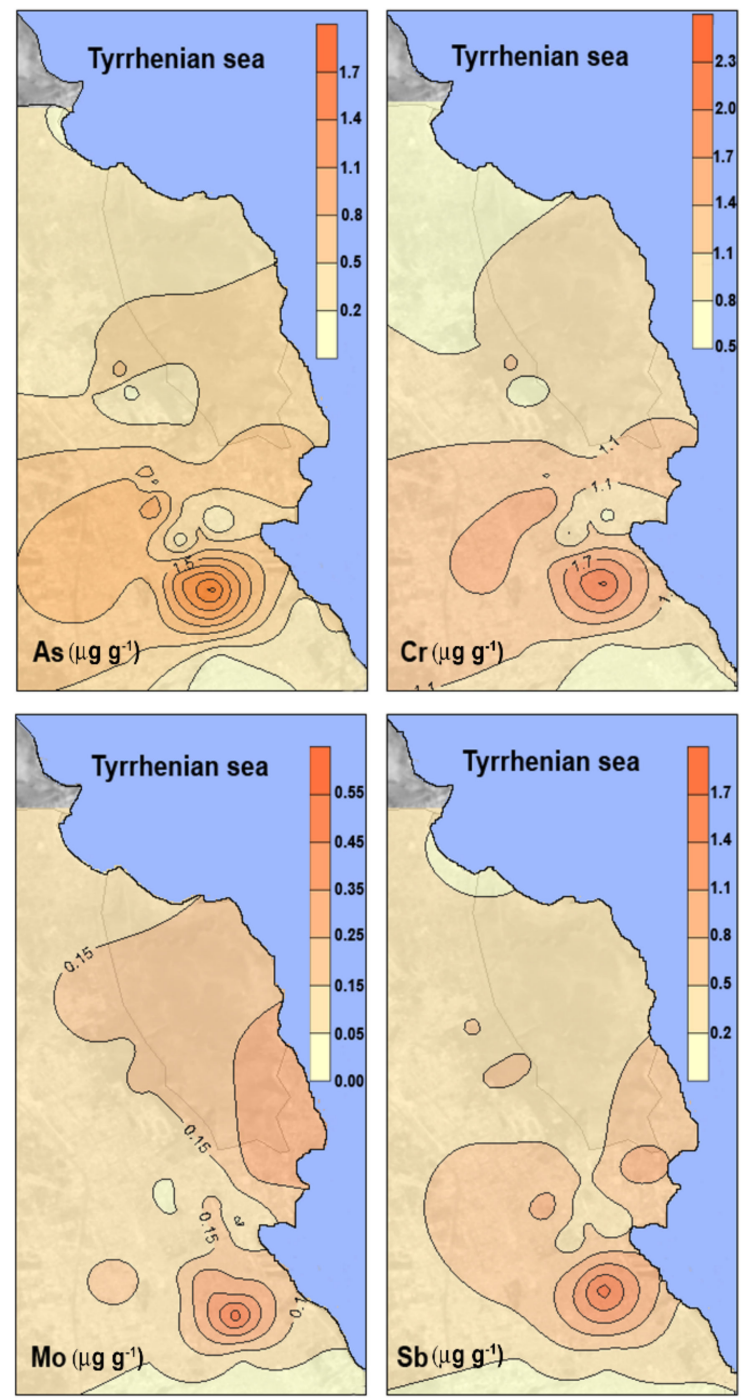

Figure 4. Areal distribution maps of As, $\mathrm{Cr}, \mathrm{Mo}$, and $\mathrm{Sb}$ in F. macrophylla leaves. Data are expressed in $\mu \mathrm{g} \mathrm{g}^{-1}$ (dry weight).

Elemental concentrations of trace elements in Ficus macrophylla leaves were statistically compared, taking the sampling site into account, using the non-parametric Mann-Whitney test with a significance level of $p<0.05$. Four out of 13 elements exhibited significant differences between the two groups (Table 4).

$\mathrm{Br}, \mathrm{Cr}, \mathrm{Mo}$, and $\mathrm{Sb}$ had much higher concentrations in urban sites than in city gardens, as shown in Figure 5.

\section{Effect of As, Cr, Mo, and Sb on Human Health}

Many trace elements are nutritionally important for human growth, but "All things are poison and nothing is without poison. Solely the dose determines that a thing is not a poison" (Omnia venenum sunt: nec sine veneno quicquam existit. Dosis sola facit, ut venenum non fit, Paracelsus, 1493-1541).

Air pollutants can have different effects on human health. The dangerousness and possible toxicity of some elements can be caused by different factors, including composition, dose, and time of exposure [11]. The human body comes into contact with trace elements through different paths that can be grouped into three broad categories: respiration, ingestion of food and water, and absorption through the skin. 
Table 4. Non-parametric Mann-Whitney test between leaf samples from urban and city-garden sites $(p<0.05)$.

\begin{tabular}{cccc}
\hline & N. URB & N. CG & $p$ Level \\
\hline As & 24 & 13 & 0.11 \\
Ba & 24 & 13 & 0.15 \\
Br & 24 & 13 & $\mathbf{0 . 0 3}$ \\
Cr & 24 & 13 & $\mathbf{0 . 0 0 3}$ \\
Cu & 25 & 14 & 0.38 \\
Mo & 24 & 13 & $\mathbf{0 . 0 3}$ \\
Mn & 25 & 14 & 0.32 \\
Pb & 25 & 14 & 0.22 \\
Rb & 24 & 13 & 1.00 \\
Sb & 24 & 13 & $\mathbf{0 . 0 1}$ \\
Sc & 24 & 13 & 0.81 \\
Sr & 25 & 14 & 0.07 \\
Zn & 25 & 14 & 0.27 \\
\hline
\end{tabular}
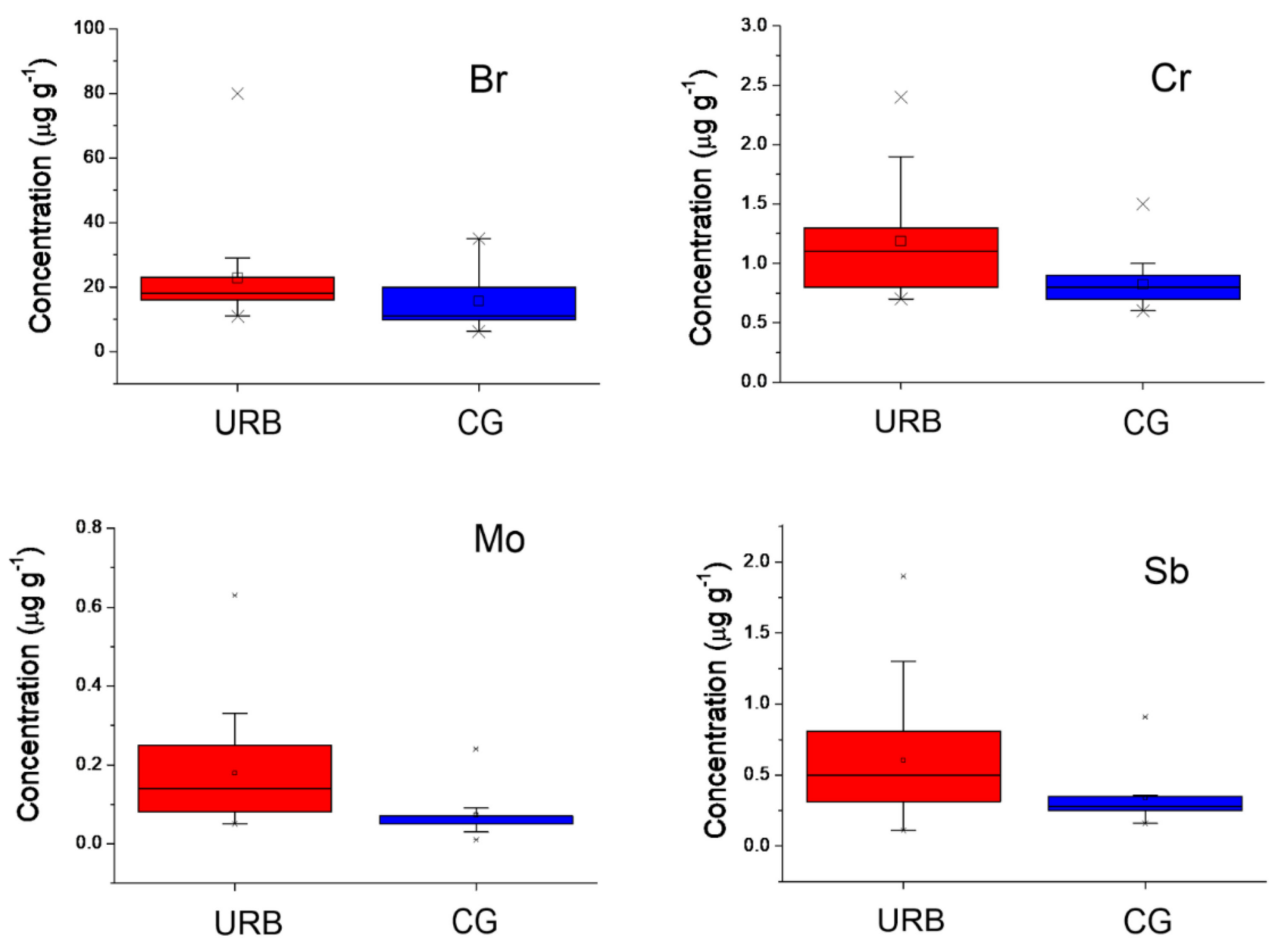

Figure 5. Box and whisker plots displaying medians, quartiles, and extremes of $\mathrm{Br}, \mathrm{Cr}$, $\mathrm{Mo}$, and $\mathrm{Sb}$ concentrations in Ficus macrophylla samples. Box interquartile ranges (25-75\%) with median indication are shown by solid lines; vertical lines outside the box (whiskers) indicate the range (1-99\%) between the highest and lowest observations, excluding the minimum and maximum. Data are given in $\mu \mathrm{g} \mathrm{g}^{-1}$ (dry biomass).

The toxic effects of trace elements, apart from their inducing oxidative stress, can also be attributed to their ability to substitute diverse polyvalent cations (calcium, zinc, and magnesium). Metals accumulate in cellular organelles binding to proteins [58] and inhibiting a large number of enzymes [59].

Arsenic is a naturally occurring element that is widely distributed in the Earth's crust. Arsenic is classified chemically as a metalloid. Arsenic exposure might cause, in addition to nucleic damage, disruption of mitochondrial and ribosomal function as well as modulation of proliferative and inflammatory pathways [60]. It is also a potent enzyme inhibitors [61,62]. Inorganic arsenic is a 
confirmed carcinogen that can also cause cardiovascular, respiratory, gastrointestinal, and neurological problems. Long-term exposure to high levels of inorganic arsenic can lead to local irritation and dermatitis [63].

Chromium is a transition element and has a different effect on human health depending on its oxidation state (Cr III or VI). Hexavalent chromium is toxic and carcinogenic; its toxicity derives from its ability to diffuse through cell membranes and oxidize biological molecules $[64,65]$. The main health problems caused by chromium are bronchial asthma, ulcers, lung and nasal tumors, skin allergies, and reproductive and developmental problems. Trivalent chromium, on the other hand, is nontoxic and an essential nutrient.

Molybdenum exists in several valence states. It can interact with the enzymatic system. Though an essential element in tiny amounts, it can be highly toxic in large doses. Exposure to too much molybdenum dust can manifest itself through systemic, immunological, neurological, and carcinogenic effects on human health [66,67].

Antimony toxicity depends on its chemical state; it does not cause strong ecotoxicological effects but can be mutagenic. Trivalent compounds have toxic effects that are about ten times greater than those of pentavalent species binding to plasma cells [68]. Its primary toxicity targets are the heart, gastrointestinal tract, musculoskeletal system, liver, and pancreas [69].

\section{Conclusions}

In this work, the leaves of Ficus macrophylla Desf. ex Pers. were used as biomonitors to assess air pollution in the urban environment. Sufficient evidence was provided which demonstrated the accumulation of metals and metalloids in the leaves of F. macrophylla collected in different Palermo sites. This sampling method is highly recommended as an economical and accessible means of detecting and monitoring inorganic pollutants in atmospheric dust. These data revealed the multitude of sources that contribute to the atmospheric particulate matter of the city of Palermo, ranging from anthropogenic sources linked exclusively to gaseous emissions and the deterioration of the mechanical parts of motor vehicles, to geogenic sources that include both sea spray and the resuspension of soil dust.

Vehicular emissions, known to be dangerous to human health, also have a negative impact on the life cycle of plants.

The present study has confirmed that Ficus macrophylla Desf. ex Pers. leaves are suitable for screening an urban environment as they have a high tolerance to pollutants. The introduction of these plants in urban areas is desirable, as they function as biofilters of atmospheric pollution, accumulating toxic metals in their leaf and root systems, and making the environment less toxic.

Author Contributions: Conceptualization, D.V. and M.G.A.; Data curation, D.V. and M.G.A.; Formal analysis, D.V. and M.G.A.; Funding acquisition, D.V.; Writing-Original draft, D.V. and M.G.A. All authors have read and agreed to the published version of the manuscript.

Funding: This work was supported by Miur (funds FFR2018, D. Varrica).

Conflicts of Interest: The authors declare no conflict of interest.

\section{References}

1. Varrica, D.; Tamburo, E.; Vultaggio, M.; Di Carlo, I. ATR-FTIR Spectral analysis and soluble components of $\mathrm{PM}_{10}$ and $\mathrm{PM}_{2.5}$ particulate matter over the urban area of Palermo (Italy) during normal days and saharan events. Int. J. Environ. Res. Public Health 2019, 16, 2507. [CrossRef]

2. Nriagu, J.O.; Pacyna, J.M. Quantitative assessment of worldwide contamination of air, water and soils by trace metals. Nature 1988, 333, 134-139. [CrossRef]

3. Santos, R.S.; Sanches, F.A.C.R.A.; Leitão, R.G.; Leitão, C.C.G.; Oliveira, D.F.; Anjos, M.J.; Assis, J.T. Multielemental analysis in Nerium Oleander L. leaves as a way of assessing the levels of urban air pollution by heavy metals. Appl. Radiat. Isotopes 2019, 152, 18-24. [CrossRef] 
4. Van Donkelaar, A.; Martin, R.V.; Michael Brauer, M.; Boys, B.L. Use of Satellite Observations for Long-Term Exposure Assessment of Global Concentrations of Fine Particulate Matter. Environ. Health Perspect. 2015, 123, 135-143. [CrossRef]

5. Bing, H.; Wu, Y.; Li, J.; Xiang, Z.; Luo, X.; Zhou, J.; Sun, H.; Zhang, G. Biomonitoring trace element contamination impacted by atmospheric deposition in China's remote mountains. Atmos. Res. 2019, 224, 30-41. [CrossRef]

6. Liu, M.; Xue, X.; Zhou, B.; Zhang, Y.; Baijun, S.; Chen, J.; Li, X. Population susceptibility differences and effects of air pollution on cardiovascular mortality: Epidemiological evidence from a time-series study. Environ. Sci. Pollut. Res. 2019, 26, 15943-15952. [CrossRef] [PubMed]

7. Berend, N. Contribution of air pollution to COPD and small airway dysfunction. Respirology 2016, 21, 237-244. [CrossRef] [PubMed]

8. Miller, K.A.; Siscovick, D.S.; Sheppard, K.; Sullivan, J.H.; Anderson, G.L.; Kaufman, J.D. Long-term exposure to costituents of fine particulate air pollution and incidence of cardiovascular events in women. New Engl. J. Med. 2007, 356, 447-458. [CrossRef] [PubMed]

9. Franklin, B.A.; Brook, R.; Pope, A. Air pollution and cardiovascular disease. Curr. Probl. Cardiol. 2015, 40, 207-238. [CrossRef] [PubMed]

10. Pope, C.A.; Burnett, R.T.; Thun, M.J.; Calle, E.E.; Krewsky, D.; Ito, K.; Thurston, G.D. Lung cancer, cardiopulmonary mortality, and long-term exposure to fine particulate air pollution. JAMA 2002, 287, 1132-1141. [CrossRef] [PubMed]

11. Kampa, M.; Castanas, E. Human health effects of air pollution. Environ. Pollut. 2008, 151, 362-367. [CrossRef] [PubMed]

12. Alfani, A.; Baldantoni, D.; Maisto, G.; Bartoli, G.; Virzo De Santo, A. Temporal and spatial variation in C, N, $\mathrm{S}$ and trace element contents in the leaves of Quercus ilex within the urban area of Naples. Environ. Pollut. 2000, 109, 119-129. [CrossRef]

13. Norouzi, S.; Khademi, H.; Faz Cano, A. Using plane tree leaves for biomonitoring of dust borne heavy metals: A case study from Isfahan, Central Iran. Ecol. Indicat. 2015, 57, 64-73. [CrossRef]

14. Vázquez, S.; Martín, A.; García, M.; Españo, C.; Navarro, E. Metal uptake of Nerium oleander from aerial and underground organs and its use as a biomonitoring tool for airborne metallic pollution in cities. Environ. Sci. Pollut. Control. Ser. 2016, 23, 7582-7594. [CrossRef]

15. Urošević, M.A.; Vuković, G.; Tomašević, M. Biomonitoring of air pollution using mosses and lichens, a passive and active approach, state of the art research and perspectives. In Air, Water and Soil Pollution Science and Technology; Nova Science: Hauppauge, NY, USA, 2016.

16. Giordano, S.; Adamo, P.; Spagnuolo, V.; Tretiach, M.; Bargagli, R. Accumulation of airborne trace elements in mosses, lichens and synthetic materials exposed at urban monitoring stations: Towards a harmonization of the moss-bag technique. Chemosphere 2013, 90, 292-299. [CrossRef]

17. Zhou, X.; Chen, Q.; Liu, C.; Fang, Y. Using moss to assess airborne heavy metal pollution in Taizhou, China. Int. J. Environ. Res. Public Health 2017, 14, 430. [CrossRef]

18. Dongarrà, G.; Varrica, D. The presence of heavy metals in air particulate at Vulcano island (Italy). Sci. Total Environ. 1998, 212, 1-9. [CrossRef]

19. Varrica, D.; Aiuppa, A.; Dongarrà, G. Volcanic and anthropogenic contribution to heavy metal content in lichens from Mt. Etna and Vulcano island (Sicily). Environ. Pollut. 2000, 108, 153-162. [CrossRef]

20. Fuga, A.; Saiki, M.; Marcelli, M.P.; Saldiva, N.H. Atmospheric pollutants monitoring by analysis of epiphytic lichens. Environ. Pollut. 2008, 151, 334-340. [CrossRef]

21. Aprile, G.G.; Salvatore, M.D.; Carratù, G.; Mingo, A.; Carafa, A.M. Comparison of the suitability of two lichen species and one higher plant for monitoring airborne heavy metals. Environ. Monit. Assess. 2010, 162, 291-299. [CrossRef]

22. Alaimo, M.G.; Dongarrà, G.; Melati, M.R.; Monna, F.; Varrica, D. Recognition of environmental trace metal contamination using pine needles as bioindicators: The urban area of Palermo (Italy). Environ. Geol. 2000, 39, 914-924. [CrossRef]

23. Dongarrà, G.; Sabatino, G.; Triscari, M.; Varrica, D. The effects of anthropogenic particulate emissions on roadway dust and Nerium oleander leaves in Messina (Sicily, Italy). J. Environ. Monit. 2003, 5, 766-773. [CrossRef] 
24. Bosco, M.L.; Varrica, D.; Dongarrà, G. Case-study: Inorganic pollutants associated with particulate matter from an area near a petrochemical plant (Gela, Italy). Environ. Res. 2005, 99, 18-30. [CrossRef]

25. Ernst, W.H.O. The use of higher plants as bioindicators. In Bioindicators and Biomonitors: Principles, Concepts and Applications; Markert, B.A., Breure, A.M., Zechmeister, H.G., Eds.; Elsevier Science: Kidlington, UK, 2003.

26. Kabata-Pendias, A. Trace Elements in Soils and Plants; CRC Press: Boca Raton, FL, USA, 2001; p. 548.

27. Alfani, A.; Maisto, G.; Iovieno, P.; Rutigliano, F.A.; Bartoli, G. Leaf contamination by atmospheric pollutants as assessed by elemental analysis of leaf tissue, leaf surface deposit and soil. J. Plant. Physiol. 1996, 148, 243-248. [CrossRef]

28. Monaci, F.; Bargagli, R. Barium and other trace metals as indicators of vehicle emissions. Water Air Soil Poll. 1997, 100, 89-98. [CrossRef]

29. Monaci, F.; Moni, F.; Lanciotti, E.; Grechi, D.; Bargagli, R. Biomonitoring of airborne metals in urban environments: New tracers of vehicle emission, in place of lead. Environ. Pollut. 2000, 107, 321-327. [CrossRef]

30. Mingorance, M.D.; Rossini Oliva, S. Heavy metals content in N. Oleander leaves as urban pollution assessment. Environ. Monitoring Assess. 2006, 119, 57-68. [CrossRef]

31. Fernandez Espinosa, A.J.; Rossini Oliva, S. The composition and relationships on Nerium Oleander L. and Lantana camara L. Chemosphere 2006, 62, 1665-1672. [CrossRef]

32. Dongarrà, G.; Varrica, D.; Sabatino, G. Occurrence of Platinum, Palladium and Gold in pine needles of Pinus pinea L. from the city of Palermo (Italy). App. Geochem. 2003, 18, 109-116. [CrossRef]

33. Lehndorff, E.; Schwark, L. Biomonitoring of air quality in the Cologne conturbation using pine needles as a passive sampler-Part III: Major and trace elements. Atmos. Environ. 2010, 44, 2822-2829. [CrossRef]

34. Turkyilmaz, A.; Sevik, H.; Çetin, M. The use of perennial needles as biomonitors for recently accumulated heavy metals. Land. Ecol. Eng. 2018, 14, 115-120. [CrossRef]

35. Rautio, P.; Huttunen, S.; Kukkola, E.; Peura, R.; Lamppu, J. Deposited particles, element concentrations and needles injuries on Scots pines along an industrial pollution transect in northern Europe. Environ. Pollut. 1998, 103, 81-89. [CrossRef]

36. Pajak, M.; Halecki, W.; Gasiorek, M. Accumulative response of Scots pine (Pinus sylvestris L.) and silver birch (Betula pendula Roth) to heavy metals enhanced by $\mathrm{Pb}-\mathrm{Zn}$ ore mining and processing plants: Explicitly spatial considerations of ordinary kriging based on a GIS approach. Chemosphere 2017, 168, 851-859. [CrossRef]

37. Guzman-Morales, J.; Morton-Bermea, O.; Hernandez-Alvarez, E.; Rodriguez-Salazar, M.T.; Garcia-Arreola, M.E.; Tapia-Cruz, V. Assessment of atmospheric metal pollution in the urban area of Mexico city, using Ficus benjamina as biomonitor. Bull. Environ. Contam. Toxicol. 2011, 86, 495-500. [CrossRef] [PubMed]

38. Rossini Oliva, S.; Rautio, P. Spatiotemporal patterns in foliar element concentrations in Ficus microcarpa L.f. growing in an urban area: Implications for biomonitoring studies. Ecol. Indic. 2005, 5, 97-107. [CrossRef]

39. Abate, B.; Catalano, R.; Renda, P.M. Schema geologico dei Monti di Palermo. Boll. Soc. Geol. It 1978, 97, 807-819.

40. Bellanca, A.; Hauser, S.; Neri, R.; Palumbo, B. Mineralogy and geochemistry of Terra Rossa soils, western Sicily: Insights into heavy metals fractionation and mobility. Sci. Total Environ. 1996, 193, 57-67. [CrossRef]

41. Borzì, A. Diagnosi di specie nuove o critiche. Boll. R. Orto Bot. Palermo 1897, 1, 43-50.

42. Borzì, A. Le specie di Ficus viventi a plenaria nel R. Orto Botanico di Palermo. Boll. R. Orto Bot. Palermo 1897, 1, 156-161.

43. Fici, S.; Raimondo, F.M. On the real identity of Ficus Magnolioides. Curtis's Bot. Mag. 1996, 13, $105-107$. [CrossRef]

44. Aquila, G.; Speciale, M. Studio dendrometrico e distributive degli esemplari monumentali di Ficus magnolioides (Moraceae, Magnoliophyta) censiti in Sicilia. Quad. Bot. Amb. Appl. 2001, 12, 13-44.

45. Cressie, N.A.C. Statistics for Spatial Data; Wiley: New York, NY, USA, 1991.

46. Statsoft Inc. Statistica (Data Analysis Software System). 2001. Available online: www.statsoft.com (accessed on 30 January 2020).

47. Dongarrà, G.; Manno, E.; Varrica, D.; Vultaggio, M. Mass levels, crustal component and trace elements in $\mathrm{PM}_{10}$ in Palermo, Italy. Atmos. Environ. 2007, 41, 7977-7986. [CrossRef] 
48. Dongarrà, G.; Manno, E.; Varrica, D.; Vultaggio, M.; Lombardo, M. Study on ambient concentrations of $\mathrm{PM}_{10}$, $\mathrm{PM}_{10-2.5}, \mathrm{PM}_{2.5}$ and gaseous pollutants. Trace elements and chemical speciation of atmospheric particulates. Atmos. Environ. 2010, 44, 5244-5257. [CrossRef]

49. Allen, S.E.; Grimshaw, H.M.; Parkinson, J.A.; Quarmby, C. Chemical Analysis of Ecological Materials; Blackwell Scientific Publications: Oxford, UK, 1974.

50. Varrica, D.; Dongarrà, G.; Sabatino, G.; Monna, F. Inorganic geochemistry of roadway dust from the metropolitan area of Palermo (Italy). Environ. Geol. 2003, 44, 222-230. [CrossRef]

51. Farago, M.E. Plants and the Chemical Elements: Biochemistry, Uptake, Tolerance and Toxicity; VCH: Weinheim, Germany, 1994.

52. Adachi, K.; Tainosho, Y. Characterization of heavy metal particles embedded in tire dust. Environ. Int. 2004, 30, 1009-1017. [CrossRef]

53. von Uexküll, O.; Skerving, S.; Doyle, R.; Braungart, M. Antimony in brake pads-a carcinogenic component? J. Clean. Prod. 2005, 13, 19-31. [CrossRef]

54. Hjortenkrans, D.; Bergbäck, B.; Häggerud, A. New metal emission patterns in road traffic environments. Environ. Monit. Assess. 2006, 117, 85-98. [CrossRef]

55. Salma, I.; Maenhaut, W. Changes in elemental composition and mass of atmospheric aerosol pollution between 1996 and 2002 in a Central European city. Environ. Pollut. 2006, 143, 479-488. [CrossRef]

56. Dongarrà, G.; Manno, E.; Varrica, D. Possible markers of traffic-related emissions. Environ. Monit. Assess 2009, 154, 117-125.

57. Varrica, D.; Bardelli, F.; Dongarrà, G.; Tamburo, E. Speciation of Sb in airborne particulate matter, vehicle brake linings, and brake pad wear residues. Atmos. Environ. 2013, 64, 18-24. [CrossRef]

58. Goering, P.L. Lead-protein interactions as a basis for lead toxicity. Neurotoxicology 1993, 14, 45. [PubMed]

59. Menzel, D.B. The toxicity of higher pollution in experimental animals and humans: The role of oxidative stresses. Toxicol. Lett. 1994, 72, 269. [CrossRef]

60. Dopp, E.; von Recklinghausen, U.; Diaz-Bone, R.; Hirner, A.V.; Rettenmeier, A.W. Cellular uptake, subcellular distribution and toxicity of arsenic compounds in methlylating and non -methylating cells. Environ. Res. 2010, 110, 435-442. [CrossRef] [PubMed]

61. Styblo, M.; Del Razo, L.M.; Vega, L.; Germolec, D.R.; LeCluyse, E.L.; Hamilton, G.A.; Reed, W.; Wang, C.; Cullen, W.R.; Thomas, D.J. Comparative toxicity of trivalent and pentavalent inorganic and methylated arsenicals in rat and human cells. Arch. Toxicol. 2000, 74, 289-299. [CrossRef] [PubMed]

62. Styblo, M.; Drobna, Z.; Jaspers, I.; Lin, S.; Thomas, D.J. The role of biomethylation in toxicity and carcinogenicity of arsenic: A research update. Environ. Health Perspect. 2002, 110, 767-777. [CrossRef] [PubMed]

63. Agency for Toxic Substances and Disease Registry (ATSDR). Toxicological Profile for Arsenic; Department of Health and Human Services, Public Health Service: Atlanta, GA, USA, 2007.

64. Kirti, S.; Sreemoyee, C.; Bhumika, J. Chromium Toxicity and its Health Hazards. Int. J. Adv. Res. 2015, 3, 167-172.

65. Agency for Toxic Substances and Disease Registry (ATSDR). Toxicological Profile for Chromium; Department of Health and Human Services, Public Health Service: Atlanta, GA, USA, 2012.

66. Vyskocil, A.; Viau, C. Assessment of molybdenum toxicity in humans. J. Appl. Toxicol. 1999, 19, $185-192$. [CrossRef]

67. Agency for Toxic Substances and Disease Registry (ATSDR). Toxicological Profile for Molybdenum. (Draft for Public Comment); Department of Health and Human Services, Public Health Service: Atlanta, GA, USA, 2017.

68. Krachler, M.; Emons, H. Speciation analysis of antimony by high-performance liquid chromatography inductively coupled plasma mass spectrometry using ultrasonic nebulization. Anal. Chim. Acta 2001, 429, 125-133. [CrossRef]

69. Agency for Toxic Substances and Disease Registry (ATSDR). Toxicological Profile for Antimony; Department of Health and Human Services, Public Health Service: Atlanta, GA, USA, 2019.

(C) 2020 by the authors. Licensee MDPI, Basel, Switzerland. This article is an open access article distributed under the terms and conditions of the Creative Commons Attribution (CC BY) license (http://creativecommons.org/licenses/by/4.0/). 